Bangladesh J. Bot. 44(4): 621-627, 2015 (December)

\title{
PREVALENCE OF MULTI-DRUG RESISTANT BACTERIA IN SELECTED STREET FOOD AND WATER SAMPLES
}

\author{
Anika Tabassum ${ }^{1}$, Minir Lal SaHA* and Mohammad Nurul Islam \\ Department of Botany, University of Dhaka, Dhaka 1000, Bangladesh
}

Key words: Velpuri, Bacteria, Antibiotic, Multi-drug resistance

\begin{abstract}
Present study was conducted to determine the bacteria and their multi-drug resistance pattern of Velpuri and water of Velpuri shop of different areas of Dhaka city. A total of 74 bacteria were isolated of which 26 isolates were subjected for further study. Eleven and 15 isolates from 26, were found Gram-positive and Gram-negative bacteria, respectively. Three isolates of Gram-positive bacteria were found rod shaped and spore formers which were identified as Bacillus spp. while eight isolates were found round shaped and nonspore formers and identified as Staphylococcus, Streptococcus, Planococcus, Micrococcus. In case of Gramnegative bacteria, Alcaligenes, Escherichia, Pseudomonas, Enterobacter, Proteus, Klebsiella, Yersinia were found to be associated with the samples. Among 26 isolates Pseudomonas and Planococcus were found to be dominating genera. Besides provisional identification, four selected isolates were further confirmed through molecular characterization based on 16S rDNA sequence analysis. Antibiotic sensitivity test results revealed that isolated bacteria were resistant against common antibiotics like penicillin G (80.77\%), vancomycin (61.53\%) and rifampicin (57.70\%). Among the isolates Pseudomonas, Enterobacter cloacae, Eshcherichia coli, Klebsiella, Proteus morganii, Yersinia enterocolitica were found to be multi-drug resistant which is very much alarming for the consumers.
\end{abstract}

\section{Introduction}

The poverty level of community, the demographic expansion and a continuous urbanization factors in various developing countries have led to the emergence of a novel and most dominant form of restaurants known as "street foods". Generally, street foods are ready-made foods sold by salesmen or by peddlers moving from one location to the other (Canet 1997). Due to its relatively low cost, street foods represent one of the most cost efficient forms of feeding among low earning people, students, craftsmen, and high school going students (Chauliac et al. 1998).

Increase in the world wide consumption of ready to eat (RTE) food product have resulted in increase in food borne illness associated with these products (Sivapalasingam et al. 2004).

Due to the excessive and inappropriate use of antibiotics there has been a gradual emergence of populations of antibiotic resistant bacteria, which pose a global public health problem (Komolafe 2003). Velpuri is one of the popular snacks of Dhaka. It is crispy deep fried bread which is usually served with spicy fillet made up of pulse, cucumber, onion and dressing. The dressing is made up of tamarind juice, pepper and black salt. Considering all these facts the present study was undertaken to determine the bacteria associated with Velpuri and water of the Velpuri shop in different areas of Dhaka city and their multi-drug resistance pattern of the associated bacteria.

*Author for correspondence: <sahaml@yahoo.com>. ${ }^{1}$ Department of Botany, Jagannath University, Dhaka -1100, Bangladesh. 


\section{Materials and Methods}

Samples were collected from different sites of Dhaka city viz., Moghbazar (MB), Dhaka Medical College (DMC), Bangladesh University of Science and Technology (BUET), Kalabagan (KB), Mirpur-1(MP-1), Teacher Students Centre (TSC), Jagannath University campus (JU), Chankharpul (CP), Curzon Hall (CH), Science Annex (SA) and Udayan School (US). Samples were collected in sterile containers and brought to the laboratory immediately for bacteriological analysis. Microbiological analysis were carried out by ten-fold serial dilution (Greenberg et al. 1998) and plated on nutrient agar, MacConkey agar, Salmonella-Shigella (SS) agar, and Cetrimide agar media were used for isolation of bacterial strains. The morphological, cultural and biochemical studies of the selected isolates were done following standard laboratory manuals (Sneath et al. 1986, Krieg and Holt 1984, SAB 1957, Collins and Lyne 1984, APHA 1998). Antibiotic susceptibility test was performed by the Kirby-Bauer disc diffusion method on MuellerHinton agar plate (Hudzicki 2012). After incubation at $37^{\circ} \mathrm{C}$ for $24 \mathrm{hrs,} \mathrm{zone} \mathrm{diameter} \mathrm{around} \mathrm{the}$ disc was measured and isolates were classified as susceptible (S), intermediately resistant (I) and resistant $(\mathrm{R})$. Nine antibiotics viz., penicillin (10 U), neomycin $(30 \mu \mathrm{g})$, gentamycin $(10 \mu \mathrm{g})$, streptomycin $(10 \mu \mathrm{g})$, doxycyclin $(30 \mu \mathrm{g})$, ciprofloxacin $(5 \mu \mathrm{g})$, vancomycin $(30 \mu \mathrm{g})$, rifampicin (5 $\mu \mathrm{g})$, polymyxin B (300 U) were tested.

Four conventionally identified isolates were subjected to molecular identification based on 16S rDNA sequence analysis for further confirmation. The following primer pairs were used- 5'16S rRNA: CCAGACTCCTACGGGAGGCAGC, 3'-16S rRNA: CTTGTGCGGGCCCCCGT CAATTC for the partial amplification of 16S rRNA gene. Supernatant of heat lysed cell suspension was used as the source of template DNA during PCR amplification of 16S rRNA gene. The PCR reaction was performed following an initial denaturation at $95^{\circ} \mathrm{C}$ for 5 mins., denaturation at $94^{\circ} \mathrm{C}$ for $1 \mathrm{~min}$., annealing at $55^{\circ} \mathrm{C}$ for $30 \mathrm{sec}$., extension at $72^{\circ} \mathrm{C}$ for $1 \mathrm{~min}$., and final extension was at $72^{\circ} \mathrm{C}$ for 10 mins. After completion of cycling program, the reactions were held at $4^{\circ} \mathrm{C}$. The amplified products were separated electrophoretically on $1 \%$ agarose gel. DNA bands were observed on UV-transilluminator and photographed by a gel documentation system (Microdoc DI-HD, MUV21-254/365, Cleaver Scientific). The sequence generated from automated sequencing of PCR products were analyzed through NCBI-BLAST database (http://blast. ncbi.nlm.nih.gov/) and rRNA BLAST (http://bioinformatics.psb.ugent.be/cgi-bin/rRNA/ blastform.cgi) programs to find out possible similar organism through alignment of homologous sequences.

\section{Results and Discussion}

During this study 74 discrete bacterial colonies were primarily selected and finally 26 bacterial isolates were studied in detailed for identification and their multi-drug resistance pattern. Considering morphology, Gram reaction and major biochemical tests and following Bergey's Manual of Systematic Bacteriology (Sneath et al. 1986) isolated bacteria were conventionally identified. Among Gram-positive three isolates (W-7, V-3, V-13) were Bacillus, four isolates (W9, W-10, V-9, V-11) were Planococcus, two isolates (V-10, V-12) were Streptococcus, one isolate (T-3) was Micrococcus and the remaining one (W-8) was the member of Staphylococcus. The isolated Gram-negative members were Alcaligenes (W-1, W-3, W-5, W-6), Pseudomonas (W-2, W-4, W-5, V-7, V-8), Klebsiella (V-2, V-3), Yersinia (V-4), Enterobacter (V-5), Proteus (V-6), Escherichia (T-1).

The relative abundance of the isolated bacteria associated with Velpuri and water of the Velpuri shop was shown in Table 1. The Gram-positive Planococcus was the dominating member (36\%) followed by Gram-negative Pseudomonas (33\%). E. coli, Proteus, Yersinia and 
Enterobacter were found to be less frequent in comparison to other members. Four isolates (W-2, W-4, V-2 and V-5) were selected for molecular identification. DNA from all the four isolates was

Table 1. Bacterial abundance in Velpuri and water.

\begin{tabular}{|c|c|c|}
\hline Name of organisms & Number of occurrence & Abundance (\%). \\
\hline \multicolumn{3}{|c|}{ Gram-positive bacteria } \\
\hline Planococcus & 4 & 36 \\
\hline Bacillus & 3 & 27 \\
\hline Streptococcus & 2 & 18 \\
\hline Micrococcus & 1 & 9 \\
\hline Staphylococcus & 1 & 9 \\
\hline \multicolumn{3}{|c|}{ Gram-negative bacteria } \\
\hline Pseudomonas & 5 & 33 \\
\hline Alcaligenes & 4 & 26 \\
\hline Klebsiella & 2 & 13 \\
\hline Yersinia & 1 & 6 \\
\hline Enterobacter & 1 & 6 \\
\hline Proteus & 1 & 6 \\
\hline Escheichia coli & 1 & 6 \\
\hline
\end{tabular}

subjected to PCR amplification and the products were separated in $1.0 \%$ agarose gel through electrophoresis. In the gel approximate size of the amplified DNA band was observed as $600 \mathrm{bp}$ (Fig. 1). The amplified DNA was sequenced and the bacterial isolate $\mathrm{W}-2$ was identified as Pseudomonas mendocina, the isolate W-4 was identified as Pseudomonas sp. the isolate V-2 was identified as Klebsiella pneumoniae and the isolate V-5 was identified as Enterobacter cloaceae through NCBI-BLAST and rRNA BLAST analysis. All the four isolates matched with their conventional identification (Table 2).

Table 2. Conventional and molecular identification of four selected isolates.

\begin{tabular}{|c|c|c|c|c|c|c|}
\hline \multirow{2}{*}{$\begin{array}{l}\text { Isolate } \\
\text { name }\end{array}$} & \multirow{2}{*}{$\begin{array}{l}\text { Conventional } \\
\text { identification }\end{array}$} & \multicolumn{4}{|c|}{ Molecular identification } & \multirow[b]{2}{*}{ E-value } \\
\hline & & $\begin{array}{l}\text { Scientific } \\
\text { name }\end{array}$ & Strain & $\begin{array}{c}\text { Identity } \\
\text { match } \\
(\%)\end{array}$ & $\begin{array}{l}\text { Max. } \\
\text { coverage } \\
\text { score }\end{array}$ & \\
\hline W-2 & $\begin{array}{l}\text { Pseudomonas } \\
\text { mendocina }\end{array}$ & P. mendocina & $13-2$ & 100 & 913 & 0.0 \\
\hline W-4 & Pseudomonas sp. & Pseudomonas sp. & ZJY-484 & 99 & 989 & 0.0 \\
\hline $\mathrm{V}-2$ & $\begin{array}{l}\text { Klebsiella } \\
\text { pneumoniae }\end{array}$ & K. pneumoniae & IW4 & 96 & 896 & 0.0 \\
\hline V-5 & $\begin{array}{l}\text { Enterobacter } \\
\text { cloaceae }\end{array}$ & E. cloaceae & TRC-322 & 83 & 183 & $1 e-42$ \\
\hline
\end{tabular}

The microbial load and the presence of the bacterial pathogens in foods are a good indication of the food quality and the potential health risk they pose to consumers (Rosmini et al. 2002). Staphylococcus aureus was isolated from water samples, which are the most predominantly virulent human Staphylococcus pathogens causing a wide range of diseases (Wertheim et al. 2005). 


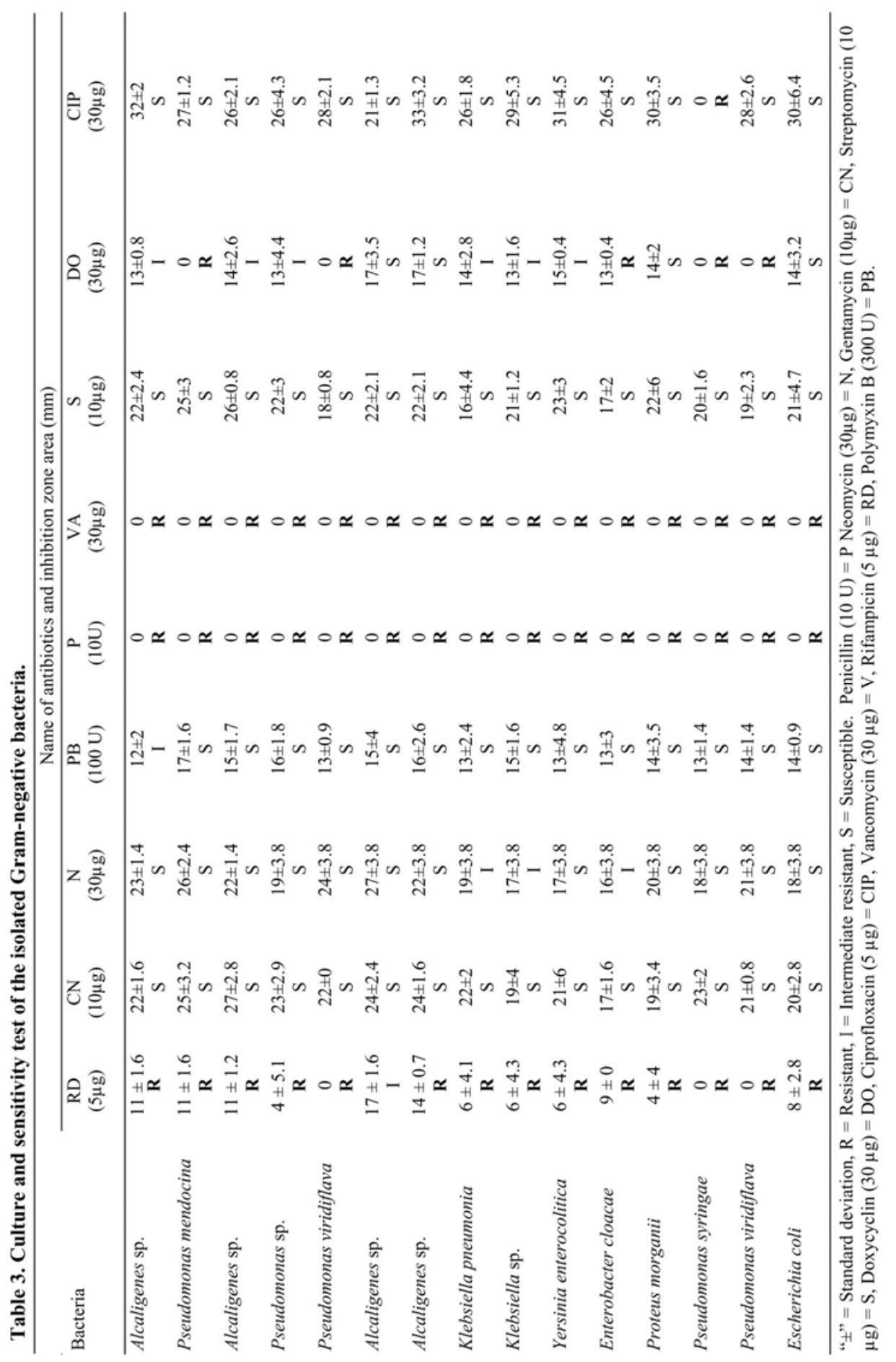




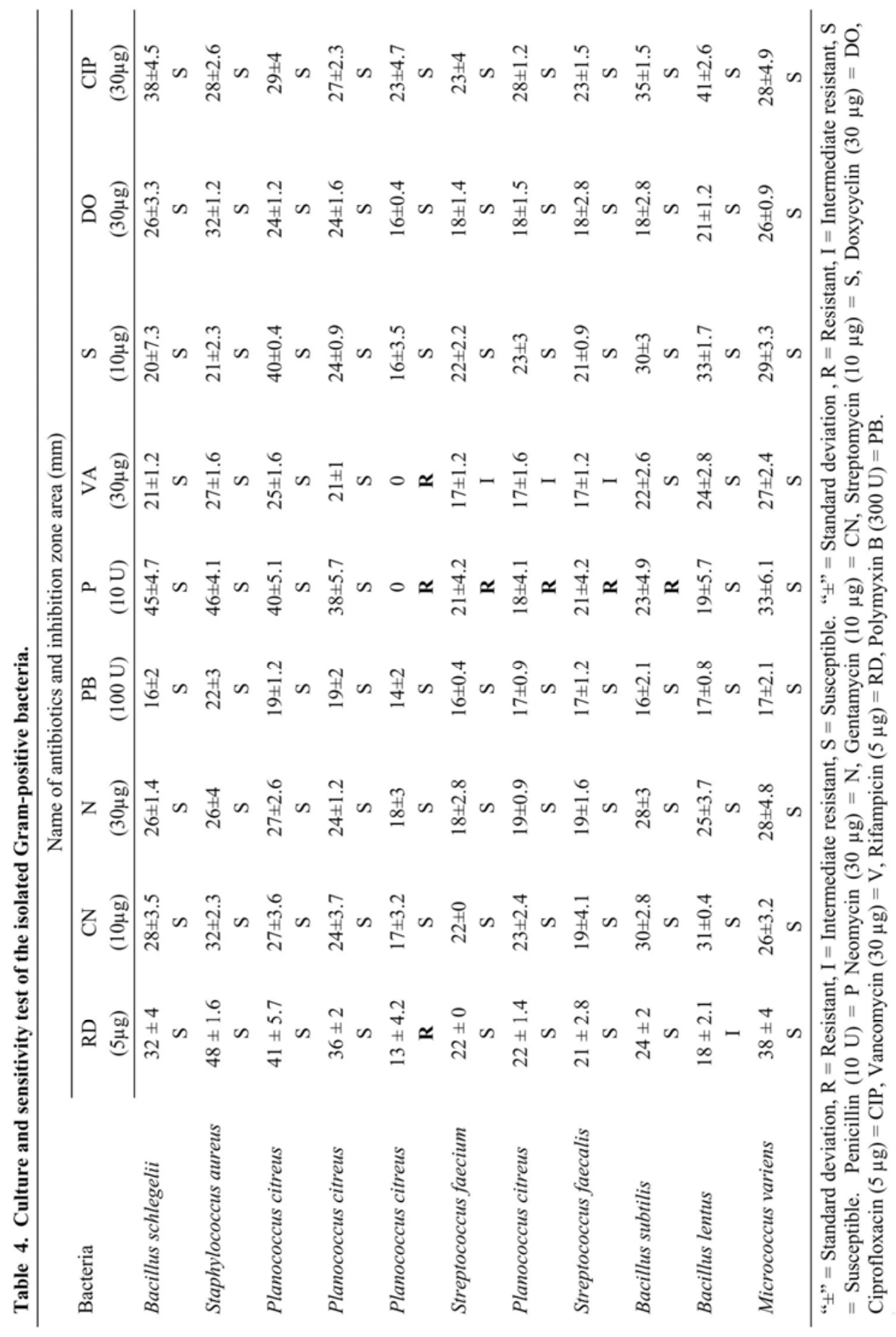




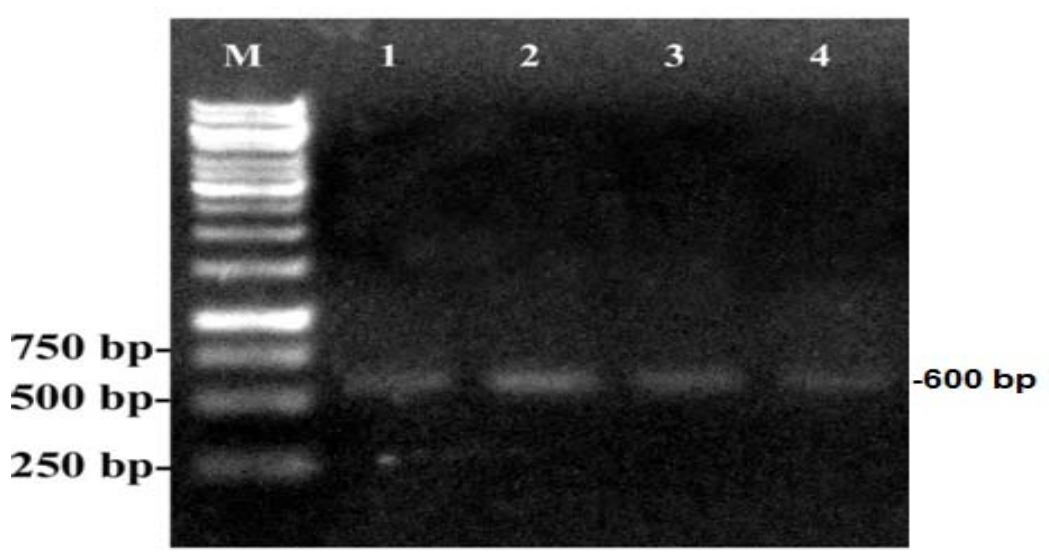

Fig. 1. PCR amplification of part of the $16 \mathrm{~S}$ rRNA gene. Lane $\mathrm{M}=1.0 \mathrm{~kb}$ ladder, lanes 1 - 4 represent four different bacterial isolates viz. W-2, W-4, V-2 and V-5. In the gel approximate size of the amplified DNA band was $600 \mathrm{bp}$.

Results of the culture and sensitivity (C/S) test of the Gram negative bacteria were shown in Table 3. Gram-negative bacteria associated with the samples were found to be resistant against common antibiotics like rifampicin, penicillin G and vancomycin. Pseudomonas syringae was found to be resistant against five antibiotics tested viz. Rifampicin, penicillin G, vancomycin, doxycyclin and ciprofloxacin. In case of Gram-positive bacteria the results were found to be different and most of the Gram positive bacteria were susceptible against common antibiotics tested (Table 4). In a study, Ali et al. (2011) observed that bacteria associated with RTE fresh vegetables and fruits most were resistant to penicillin and vancomycin. In the present study similar result was observed. The result clearly indicated that waterborne pathogens are becoming resistant to penicillin and vancomycin. Multidrug-resistant enteric bacteria were isolated from Turkey, cattle, and chicken farms and retail meat products in Oklahoma. A total of 132 isolates of Klebsiella pneumoniae were characterized and all isolates were found to be resistant to ampicillin, tetracycline, streptomycin, gentamycin, and kanamycin (Kim et al. 2005). In the present study Klebsiella pneumoniae was found to be resistant against rifampicin, penicillin $\mathrm{G}$ and vancomycin and Klebsiella sp.

In this study Pseudomonas syringae showed resistance against five antibiotics. Among the isolated bacteria Pseudomonas, Enterobacter cloacae, Eshcherichia coli, Klebsiella, Proteus morganii, Yersinia enterocolitica were found to be multidrug resistant. The presence of both Gram-negative and Gram-positive members viz. E. coli, Enterobacter, Klebsiella, Alcaligenes, Staphylococcus, Streptococcus etc. in Velpuri a popular snacks and their multi-drug resistance raises serious food and water safety concerns.

\section{References}

Ali M, Khan MR and Saha ML 2011. Antibiotic resistance pattern of bacterial isolates from ready-to-eat (RTE) street vended fresh vegetables and fruits in Dhaka city, Bangladesh J. Sci. Res. 24(2): 127-134.

APHA 1998. Standard Methods for the Examination of Water and Wastewater (20 ${ }^{\text {th }}$ ed.) APHA/AWWA/ WEF, Washington DC, USA. pp.1325.

Chauliac M, Bricas N, Ategbo E, Amoussa W and Zohoun I 1998. Food habits outside the home by School children in Cotonou (Benin). Santé 8(2): 101-108. 
Collins CH and Lyne PM 1984. Microbiological methods (5th ed.). Butterworth and Co. Publishers Ltd. London. pp. 448.

Greenberg AE, Connors JJ, Jenkins DGJ and Franson MAH . 1998. Standard methods for examination of water and wastewater (20th ed.). APHA. Washington DC.

Hudzicki J 2012. Kirby-Bauer disk diffusion susceptibility test protocol. Microbe library. American Society for Microbiology. pp. 1-29.

Kim SH, Wei CI, Tzou YM and An H 2005. Multidrug-resistant Klebsiella pneumoniae isolated from farm environments and retail products in Oklahoma. J. Food Prot. 68(10): 2022-9.

Komolafe OO 2003. Antibiotic resistance in bacteria an emerging public health problem. Malawi Medical J. 15(2): 63 - 67.

Krieg NR and Holt JG 1984. Bergey’s Manual of Systematic Bacteriology. Vol. 1. Williams and Wilkins Company, Baltimore. pp. 964.

Rosmini MR, Signorini ML, Schneider R and Bonazza JC 2004. Evaluation of two alternative techniques for counting mesophilic aerobic bacteria in raw milk. Food Control. 15(1): 39-44.

SAB (Society of American Bacteriologists) 1957. Manual of Microbiological Methods. McGraw-Hill Book Co. Inc. NY. pp. 315.

Sivapalasingam S, Friedman CR, Cohen L and Tauxe RV 2004. Fresh produce: A growing cause of outbreaks of food borne illness in the United States, 1973 through 1997. J. Food Prot. 67(10): 2342-2353.

Sneath PHA, Mair, Sharpe ME and Holt JG 1986. Bergey’s Manual of Systematic Bacteriology (9 ${ }^{\text {th }}$ ed.). Williams and Wilkins Company, Baltimore. London.

Wertheim H, Van B, Melles D, Verbrugh H, Nouwen J, Van L and Vos M 2005. The role of nasal carriage in Staphylococcus aureus infections. Lancet Infection Disease 5: 751-762.

(Manuscript received on 31 May, 2015; revised on 8 November, 2015) 